\title{
Venom's antinociceptive property in the primitive ant Dinoponera quadriceps
}

\author{
Paloma L. Sousa ${ }^{a}$, Yves Quinet ${ }^{a}$, Edson L. Ponte ${ }^{a}$, Jaqueline F. do Vale ${ }^{\mathrm{a}}$, Alba Fabíola C. Torres ${ }^{\mathrm{b}}$, \\ Maria G. Pereira ${ }^{a}$, Ana Maria S. Assreuy ${ }^{\mathrm{a}, *}$ \\ a Instituto Superior de Ciências Biomédicas, Universidade Estadual do Ceará-UECE, Av. Paranjana 1700, Itaperi 60 740-000, Fortaleza-CE, Brazil \\ ${ }^{\mathrm{b}}$ Departamento de Fisiologia e Farmacologia, Universidade Federal do Ceará-UFC, R. Capitão Francisco Pedro 1210, Rodolfo Teófilo 60 430-170, Fortaleza-CE, Brazil
}

\section{A R T I C L E I N F O}

\section{Article history:}

Received 9 June 2012

Received in revised form

9 August 2012

Accepted 25 August 2012

Available online 1 September 2012

\section{Keywords:}

Antinociceptive

Dinoponera quadriceps

Proteic venom

Formicidae

Mice

\begin{abstract}
A B S T R A C T
Ethnopharmacological relevance: In northeastern Brazil, Dinoponera (Ponerinae) ants macerate are used to treat ear ache and its sting, rheumatism, and back pain. Such a popular use is a relevant fact that called for experimental evaluation of the antinociceptive activity of Dinoponera venom.

Materials and methods: Dinoponera quadriceps venom (DqV; 5-500 $\mu \mathrm{g} / \mathrm{kg}$; i.v.) or morphine (3.4 mg/kg; s.c.) were evaluated in mice models of nociception ( $n=8$ animals/group). Negative controls received sterile saline (0.9\% $\mathrm{NaCl}$; i.v.).

Results: DqV showed 64\% protein content and exhibited antinociceptive activity, without affecting motor function, in the tests: formalin (72\%), writhing (52\%), von Frey (71\%) and hot plate (45\%). The antinociceptive activity was abolished under protein denaturant conditions.

Conclusions: This study provided the first demonstration of the antinociceptive property of Dinoponera quadriceps venom in mice models of chemical, mechanical and thermal nociception, corroborating the popular use and suggesting its potential therapeutic utilization in painful conditions.
\end{abstract}

(c) 2012 Elsevier Ireland Ltd. All rights reserved.

\section{Introduction}

Dinoponera (Ponerinae) is a primitive and strictly Neotropical ant genus, with six known species considered the biggest ants of the world (3-4 cm in length), (Kempf, 1971). Similar to the other Dinoponera species, Dinoponera quadriceps Santschi, 1921 ("falsa tocandira", "trinca-cunhão"), has ground-dwelling habits and their common prey are medium size to large arthropods that they subdue with their sting (Araújo and Rodrigues, 2006). Like many ants of basal and more derived groups (i.e. Ponerinae, Pseudomyrmeciinae, Myrmicinae), as well as other hymenopteran species (bees and wasps), Dinoponera ants have a sting apparatus, located in the last portion of the gaster, formed by the sting itself along with two associated glands: Dufour's gland and venom gland. In ants and other hymenopterans, the main function of venom is prey capture and/or defense (Buschinger and Maschwitz, 1984; Schmidt, 1986).

Primitively, the composition of hymenopteran venoms is a complex mixture of biologically active proteins and other proteinaceous elements (Schmidt, 1986). The venom of Paraponera clavata (Ponerinae) contains a peptide (poneratoxin) that blocks sodium

\footnotetext{
* Correspondence to: Instituto Superior de Ciências Biomédicas, Universidade Estadual do Ceará, 60714-242 Fortaleza-CE, Brazil. Tel.: +55 8531019919; fax: +558531019810 .

E-mail address: anassreuy@gmail.com (A.M.S. Assreuy).
}

channels in frog skeletal muscle fibers (Duval et al., 1992). Some hymenopteran protein venom components from Apis mellifera (melittin) (Merlo et al., 2011) and from the social wasp Polybia occidentalis ( $\mathrm{Thr}^{6}$-bradykinin) exhibit antinociceptive properties (Mortari et al., 2007). Few studies have explored the use of ant venoms in the folk medicine. However, there is a description of the popular use of Dinoponera sp. for earache in Ichu-Bahia (northeastern Brazil): the product obtained from crushed ants is applied in the ear using a piece of cotton (Costa Neto, 2011). Dinoponera sp. sting is also said to be useful to treat rheumatism and back pain (Costa Neto et al., 2006). In addition, there are descriptions of Dinoponera sp. popular use for asthma treatment (Costa Neto et al., 2006; Alves and Rosa, 2007). The aim of this study is to evaluate the antinociceptive property of Dinoponera quadriceps venom in mice.

\section{Materials and methods}

\subsection{Materials}

Dinoponera quadriceps nests were collected (IBAMA authorization no. 28794-1) in the "Serra de Maranguape", a small mountain range located in the littoral zone of the Ceará state (northeastern Brazil), and kept in plastic boxes $(63 \mathrm{~cm} \times 42 \mathrm{~cm}$ and $12 \mathrm{~cm}$ high), at $30 \pm 2{ }^{\circ} \mathrm{C}$, with a $12 / 12 \mathrm{~h} \mathrm{light} /$ dark cycle, and PVC tubes $(4 \mathrm{~cm}$ in diameter, $38 \mathrm{~cm}$ in length) as nesting sites. Ants were fed ad libitum on Tenebrio molitor larvae. To collect the venom, 
Dinoponera quadriceps workers were seized in the thorax region and its sting was introduced in a capillar tube to induce venom secretion. Venom was then transferred to a tube containing $10 \mathrm{mM}$ ammonium acetate buffer ( $\mathrm{pH} 6.8$ ), lyophilized and stored at $-20{ }^{\circ} \mathrm{C}$. Protein content was evaluated by the colorimetric method $\left(A_{595} \mathrm{~nm}\right)$.

Male Swiss mice (25-35 g), maintained at $25{ }^{\circ} \mathrm{C}$ under a 12 / $12 \mathrm{~h}$ light/dark cycle with food and water ad libitum, were brought to the laboratory at least $1 \mathrm{~h}$ before the experiments, approved by the Animal Care and Use Committee (UECE11221997-7/45).

Drugs and reagents were purchased from Sigma, St. Louis, MO, USA ( $\lambda$-carrageenan), Nova Química, São Paulo, SP, Brazil (Diazepan), Isofar, Rio de Janeiro, RJ, Brazil (formaldehyde and acetic acid).

\subsection{Nociception models}

Mice ( $n=8$ animals/group) received Dinoponera quadriceps venom (DqV; $5-500 \mu \mathrm{g} / \mathrm{kg}$ ) by intravenous (i.v.) route or morphine $(3.8 \mathrm{mg} / \mathrm{kg}$ ) by subcutaneous (s.c.) route $30 \mathrm{~min}$ before injection of the nociceptive agents. Negative controls received sterile saline $(0.9 \% \mathrm{NaCl} ; 50 \mu \mathrm{L} / 10 \mathrm{~g}$ body weight; i.v.).
Formalin test: formalin $(2.5 \% \mathrm{v} / \mathrm{v} ; 20 \mu \mathrm{L} / \mathrm{paw})$ was injected by subcutaneous (s.c.) intraplantar route in the animal right hind paws and the time (s) in which they spent licking their paws was registered during the first (P1: $0-5 \mathrm{~min}$ ) and second (P2: 15$30 \mathrm{~min}$ ) phases of the test (Shibata et al., 1989).

Writhing test: acetic acid $(0.8 \% \mathrm{v} / \mathrm{v} ; 0.1 \mathrm{~mL} / 10 \mathrm{~g}$ body weight) was injected by intraperitoneal (i.p.) route and the number of abdominal writhes was registered during 10-30 min (Koster et al., 1959).

von Frey test: animals were individually placed in clear acrylic boxes with raised platforms of wire mesh to allow access to the ventral surface of hind paws from 15 to $30 \mathrm{~min}$. Hypernociception was induced by s.c. injection of $1 \%$ carrageenan ( $300 \mu \mathrm{g} / \mathrm{paw})$ and the frequency of paw withdrawal in response to six applications of the flexible von Frey filament $(0.8 \mathrm{~g})$ was measured before (T0) and from 1 to $5 \mathrm{~h}$ after carrageenan (von Frey, 1896).

Hot plate test: mice were placed on a hot plate at $55 \pm 0.5^{\circ} \mathrm{C}$ for up to $25 \mathrm{~s}$ and the reaction latency of thermal stimulus (time to start licking or shaking hind paws or jumping) was registered. Treatment with DqV at r.t. or at $100^{\circ} \mathrm{C} / 1 \mathrm{~h}$ was performed before the test. The reaction latency was recorded at baseline and after 1-5 h (Hunskaar et al., 1986).
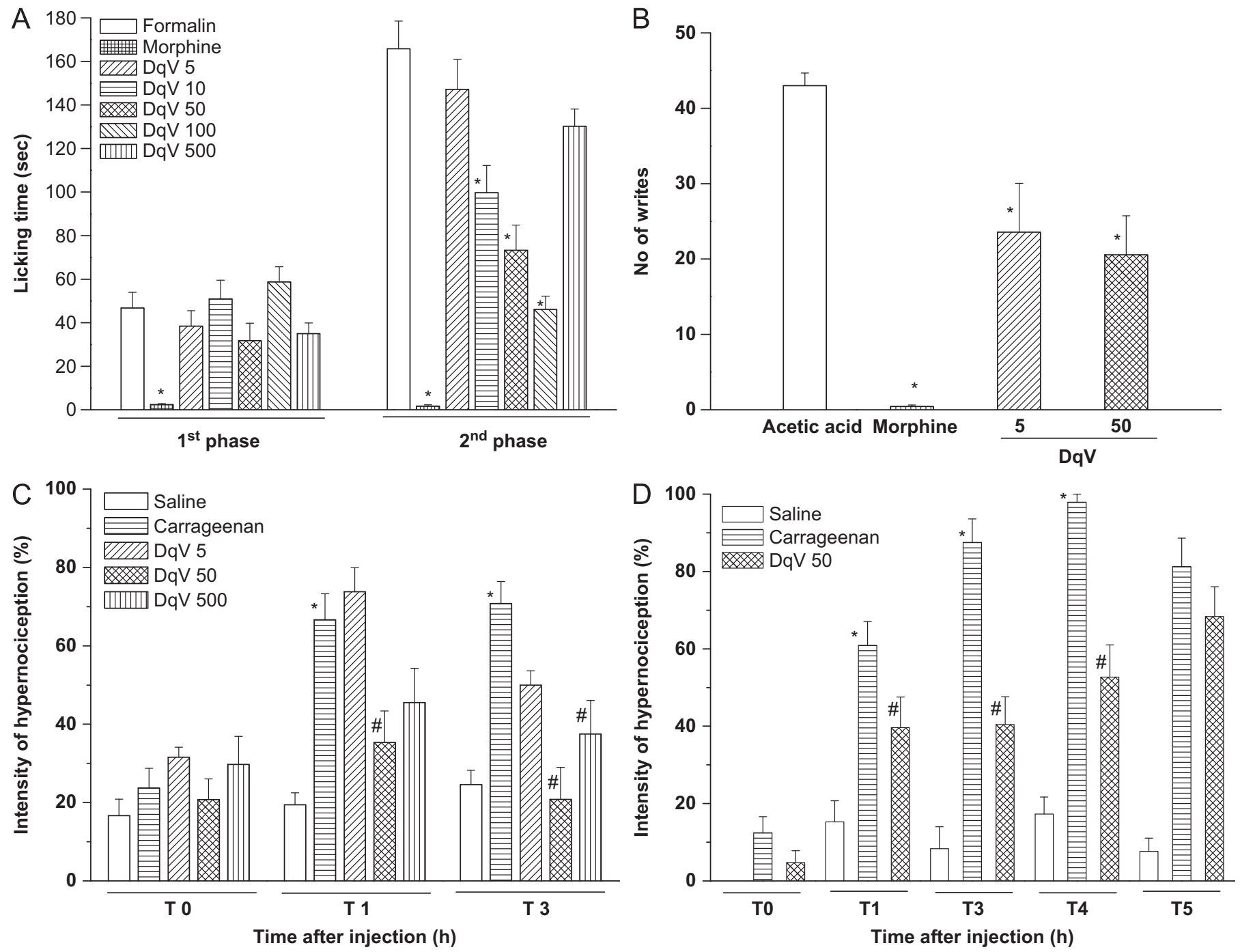

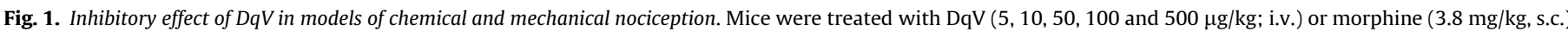

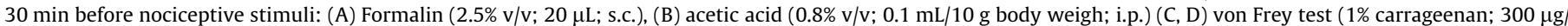
paw; s.c.). Mean \pm SEM $(n=8)$. ANOVA and Bonferroni's test. ${ }^{*} p<0.05$ vs. formalin, acetic acid or saline. ${ }^{\#} p<0.05 v s$. carrageenan. 
To verify interference in the animals motor function, DqV or diazepam was injected and the animals permanence on the rotarod was recorded (Dunham and Miya, 1957).

Results were analyzed by ANOVA and Bonferroni's test $(p<0.05)$.

\section{Results and discussion}

The first phase of the formalin test reproduces a neurogenic response, associated to direct activation of transient potential ankyrin (TRPA-1) receptors (McNamara et al., 2007), that are also involved in the second phase. Activation of these receptors leads to changes in neurons of the dorsal spinal cord and release of inflammatory mediators from peripheral tissues, such as prostaglandins, histamine, serotonin, bradykinin (Shibata et al., 1989), cytokines (Chichorro et al., 2004) and nitric oxide (NO) (Moore et al., 1991). DqV inhibited only the second phase: at $10 \mu \mathrm{g} / \mathrm{kg}$ by $40 \%(99.8 \pm 12.4 \mathrm{~s}), 50 \mu \mathrm{g} / \mathrm{kg}$ by $56 \%(73.3 \pm 11.5 \mathrm{~s})$ and $100 \mu \mathrm{g} / \mathrm{kg}$ by $72 \%(46.1 \pm 6.0 \mathrm{~s})$ and morphine nearly abolished both phases compared to formalin $(165.8 \pm 12.7 \mathrm{~s})$ (Fig. $1 \mathrm{~A})$. DqV antinociceptive effect in the second phase suggests inhibition of inflammatory process, as previously demonstrated for the venom of Apis mellifera and its protein compound melittin (Merlo et al., 2011).

The writhing test is useful for evaluation of peripheral antinociceptive activity since the intraperitoneal injection of acetic acid triggers the release of inflammatory mediators, such as bradykinin, prostaglandins, substance $\mathrm{P}$ and cytokines (Ribeiro et al., 2000) that activate chemosensitive nociceptors leading to inflammatory pain. DqV reduced the number of writhes elicited by acetic acid $(43.0 \pm 1.7)$ at $5 \mu \mathrm{g} / \mathrm{kg}$ by $45 \%(23.6 \pm 6.5)$ and at $50 \mu \mathrm{g} / \mathrm{kg}$ by $52 \%(20.6 \pm 5.2)$. Morphine completely inhibited these writhing (Fig. 1B). This result validates the antinociceptive effect of DqV, demonstrated in the formalin test, and suggests peripheral analgesic activity targeting inflammatory mediators.

The von Frey test is a hypernociception model that assesses inflammatory pain, in which the phlogistic agent carrageenan reproduces a biphasic response. The initial phase $(1-2 \mathrm{~h})$ is associated to participation of inflammatory mediators, such as histamine, serotonin and bradykinin, and the late phase (2-4 h) with prostaglandins and NO (Posadas et al., 2004). DqV inhibited the carrageenan-elicited hypernociception from 1 to $4 \mathrm{~h}$ (Fig. 1C, D): in the 1 st hour, only at $50 \mu \mathrm{g} / \mathrm{kg}$ by $47 \%$ (DqV: $35.4 \pm 8.0 \% v s$. carrageenan: $67.0 \pm 6.6 \%$ ), and in the 3rd hour, at $50 \mu \mathrm{g} / \mathrm{kg}$ by $71 \%$ $(20.8 \pm 8.2 \%)$ and $500 \mu \mathrm{g} / \mathrm{kg}$ by $47 \%(37.5 \pm 8.6 \%)$ vs. carrageenan: $70.8 \pm 5.6 \%$. DqV effect at the most active dose $(50 \mu \mathrm{g} / \mathrm{kg})$ lasted until $4 \mathrm{~h}$ after stimuli, showing $46 \%$ inhibition (DqV: $97.91 \pm$ $2.08 \% v s$. carrageenan: $52.7 \pm 8.3 \%$ ). This finding corroborates those obtained in the models previously described in this study, as well the anti-inflammatory and antinociceptive effects of other Hymenoptera venoms (Mortari et al., 2007; Merlo et al., 2011).
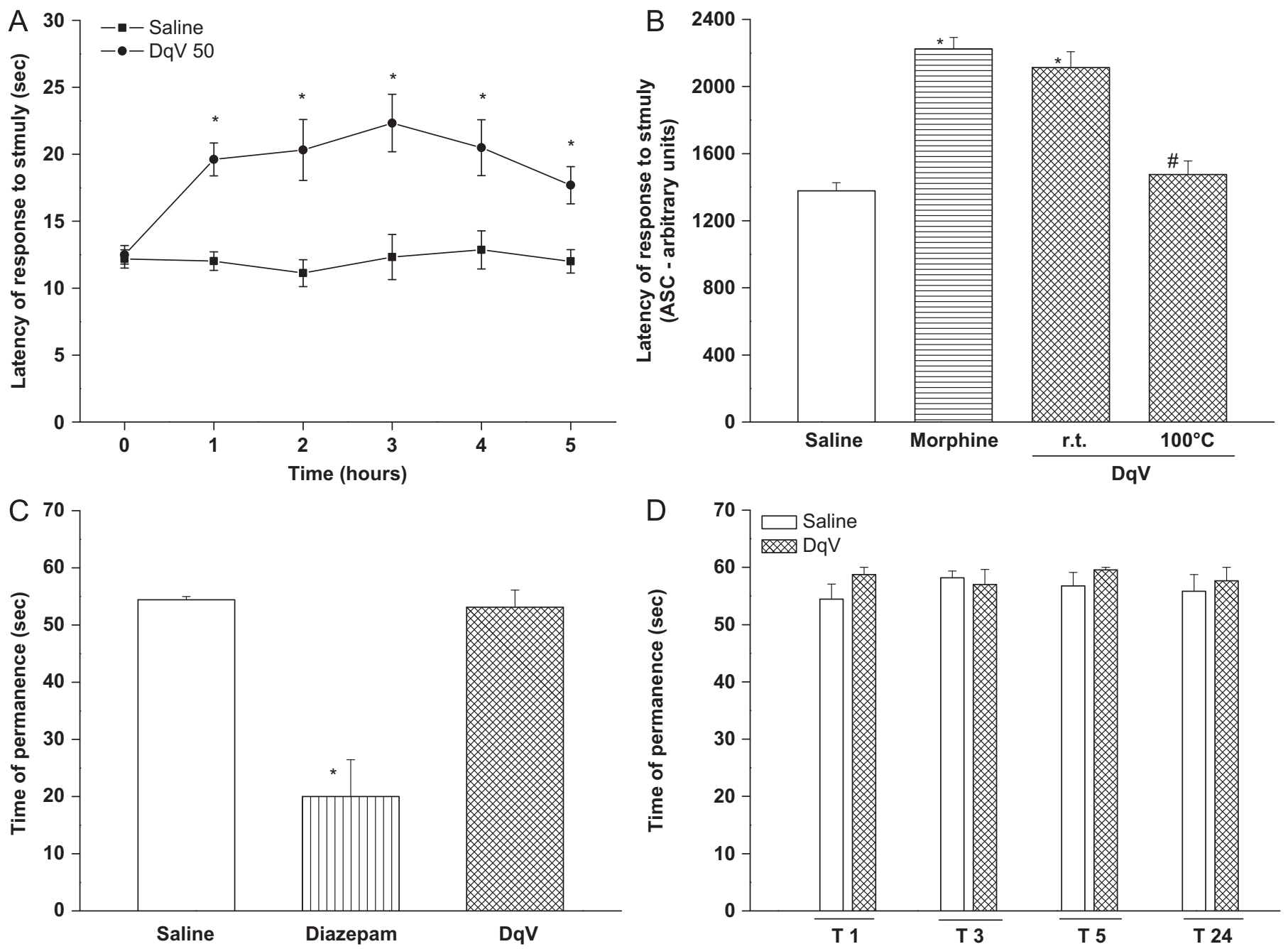

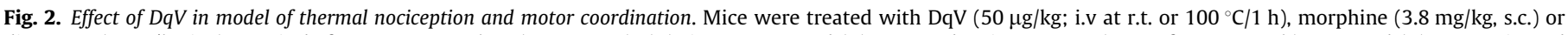

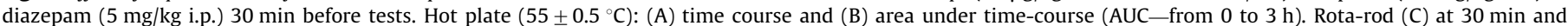
(D) from 1 to 24 h. Mean \pm SEM $(n=8)$. ANOVA and Bonferroni's test. ${ }^{*} p<0.05$ vs. saline. ${ }^{*} p<0.05 v s$. DqV (r.t.). 
The hot plate test reproduces pain associated to neurotransmission, either primarily in the spinal cord and/or higher levels of the central nervous system or via indirect mechanisms (Hunskaar et al., 1986). DqV (50 $\mu \mathrm{g} / \mathrm{kg})$ increased the latency of response to thermal stimuli from 1 to $5 \mathrm{~h}$, with maximal effect at $3 \mathrm{~h}(\mathrm{DqV}$ : $22.3 \pm 2.1 \mathrm{~s}$ vs. control: $12.3 \pm 1.6 \mathrm{~s}$ ) (Fig. $2 \mathrm{~A}$ ). Central antinociceptive effect of a bradykinin structural analog isolated from other Hymenoptera venom had been suggested (Mortari et al., 2007). Moreover, a protein component of DqV is most likely responsible for its antinociceptive effect, since proteins account for $64.4 \%$ of venom content and DqV antinociceptive activity was abolished when the venom was exposed to high temperature. Morphine, similar to DqV (r.t.), showed antinociceptive activity (Fig. 2B). Besides, as member of a basal group of predatory ants (Ponerinae), it is expected that Dinoponera quadriceps produces proteinaceous venoms. Studies with Dinoponera venoms had shown presence of proteins, as in Dinoponera australis (Johnson et al., 2010).

Another important demonstration from this study was that DqV $(50 \mu \mathrm{g} / \mathrm{kg})$, different from the sedative agent diazepam that decreased the time (s) of animals permanence $(20 \pm 6.4 \mathrm{vs}$. saline: $49.6 \pm 7.4$ ) in the rota-rod, did not interfere with animal's motor function at any time ( $30 \mathrm{~min}$, from 1 to $5 \mathrm{~h}$ and $24 \mathrm{~h}$ ) after DqV administration (Fig. 2C, D).

Summarizing, the antinociceptive property of Dinoponera quadriceps venom demonstrated here could be of clinical interest in painful conditions associated to hypernociception and allergic inflammation, simulated in our experimental models, such as rheumatism, earache and back pain, already used by the population in northeastern Brazil. The scientific validation of this property can also be extended to other pathological conditions (i.e. neuropathic pain, burns) and populations.

\section{Conclusion}

This study provided the first demonstration of the inhibitory property of the proteinaceous venom extracted from Dinoponera quadriceps in mice models of chemical, thermal and mechanical nociception, corroborating the popular use and suggesting its potential therapeutic utilization in algic conditions.

\section{Acknowledgments}

Authors acknowledge the Conselho Nacional de Desenvolvimento Científico e Tecnológico (CNPq) and Fundação Cearense de Apoio ao Desenvolvimento Científico e Tecnológico for financial support. Assreuy AMS is senior investigator of CNPq/Brazil.

\section{References}

Alves, R.R.N., Rosa, I.L., 2007. Zootherapy goes to town: the use of animal-based remedies in urban areas of $\mathrm{NE}$ and $\mathrm{N}$ Brazil. Journal of Ethnopharmacology $113,541-555$.
Araújo, A., Rodrigues, Z., 2006. Foraging behavior of the queenless ant Dinoponera quadriceps Santschi (Hymenoptera: Formicidae). Neotropical Entomology 35, 159-164.

Buschinger, A., Maschwitz, U., 1984. Defensive behavior and defensive mechanisms in ants. In: Herman, H.R. (Ed.), Defensive Mechanisms in Social Insects. Praeger, New York, pp. 95-150.

Costa Neto, E.M., Ramos-Elorduy, J., Moreno, J.M.P., 2006. Los insectos medicinales de Brasil: primeros resultados. Boletín Sociedad Entomológica Aragonesa 38, 395-414.

Costa Neto, E.M., 2011. A zooterapia popular no Estado da Bahia: registro de novas espécies animais utilizadas como recursos medicinais. Ciência and Saúde Coletiva 16, 1639-1650.

Chichorro, J.G., Lorenzetti, B.B., Zampronio, A.R., 2004. Involvement of bradykinin, cytokines, sympathetic amines and prostaglandins in formalin-induced orofacial nociception in rats. British Journal of Pharmacology 141, 1175-1184.

Dunham, N.W., Miya, T.S., 1957. A note on a simple apparatus for detecting neurological deficits in rats and mice. Journal of the American Pharmacists Association (Baltim) 46, 208-209.

Duval, A., Malécot, C.O., Pelhate, M., Piek, T., 1992. Poneratoxin, a new toxin from an ant venom, reveals an interconversion between two gating modes of the $\mathrm{Na}^{+}$channels in frog skeletal muscle fibres. Pflügers Archiv: European Journal of Physiology 420, 239-247.

Hunskaar, S., Berge, O.G., Hole, K., 1986. A modified hot-plate test sensitive to mild analgesics. Behavioural Brain Research 21, 101-108.

Johnson, S.R., Copello, J.A., Steven, M.E., Suarez, A.V., 2010. A biochemical characterization of the major peptides from the venom of the giant neotropical hunting ant Dinoponera australis. Toxicon 55, 702-710.

Kempf, W.W., 1971. A preliminary review of the ponerine ant genus Dinoponera Roger (Hymenoptera: Formicidae). Studia Entomologica 14, 369-394.

Koster, R., Anderson, M., Debeer, E.J., 1959. Acetic-acid for analgesic screening. Federation Proceedings 18, 412-418.

McNamara, C.R., Mandel-Brehm, J., Bautista, D.M., Siemens, J., Deranian, K.L., Zhao M., Hayward, N.J., Chong, J.A., Julius, D., Moran, M.M., Fanger, C.M., 2007. TRPA1 mediates formalin-induced pain. Proceedings of the National Academy of Sciences 104, 13525-13530.

Merlo, L.A., Bastos, L.F.S., Gondin, A.M., Rocha, L.T.S., Nascimento, E.B., Paiva Jr., A.L.L., Moraes-Santos, T., Zumpano, A.A.C., Bastos, E.M.A.F., Heneine, L.G.D., Coelho, M.M., 2011. Effects induced by Apis mellifera venom and its components in experimental models of nociceptive and inflammatory pain. Toxicon 57, 764-771.

Moore, P.K., Oluyomi, A.O., Babbedge, R.C., Wallace, P., Hart, S.L., 1991. L-NG-nitro arginine methyl ester exhibits antinociceptive activity in the mouse. British Journal of Pharmacology 102, 198-202.

Mortari, M.R., Cunha, A.O., Carolino, R.O., Coutinho-Netto, J., Tomaz, J.C., Lopes N.P., Coimbra, N.C., Dos Santos, W.F., 2007. Inhibition of acute nociceptive responses in rats after i.c.v. injection of Thr6-bradykinin isolated from the venom of the social wasp Polybia occidentalis. British Journal of Pharmacology $151,860-869$.

Posadas, I., Bucci, M., Roviezzo, F., Rossi, A., Parente, L., Sautebin, L., Cirino, G., 2004 Carrageenan-induced mouse paw oedema is biphasic, age-weight dependent and displays differential nitric oxide and cyclooxygenase- 2 expression. British Journal of Pharmacology 142, 331-338.

Ribeiro, R.A., Vale, M.L., Thomazzi, S.M., 2000. Involvement of resident macrophages and mast cells in the writhing nociceptive response induced by zimosan and acetic acid in mice. European Journal of Pharmacology 387, $111-118$.

Schmidt, J.O., 1986. Chemistry, pharmacology, and chemical ecology of ants venoms. In: Pick, T. (Ed.), Venom of the Hymenoptera. Academic Press, New York, pp. 425-508.

Shibata, M., Ohkubo, T., Takahashi, H., Inoki, R., 1989. Modified formalin test: characteristic biphasic pain response. Pain 38, 347-352.

von Frey, M., 1896. Untersuchunger über die Sinnesfunctionen der menschlichen Haut. Bandes der Abhandlungen der mathematischphysischen Classe der Königl. Sächsischen Gesellschaft der Wissenschaften 23, 175-266. 